\title{
Significance of pelagic and benthic metabolism for the carbon budget of a shallow lake
}

\author{
Magdalena Wielgat-Rychert* and Krzysztof Rychert \\ Institute of Biology and Environmental Protection, Pomeranian University in Słupsk, ul. Arciszewskiego 22b, 76-200 Słupsk, Poland
}

Received 14 July 2016; Accepted 9 November 2016

\begin{abstract}
Pelagic and benthic primary production and respiration were measured at an offshore station in the shallow, $1.2 \mathrm{~m}$ deep, polymictic Lake Gardno (Poland) to examine the role of the pelagic zone and the sediments in the overall carbon budget of this lake. The respiration rates in the sediments were within the same range of values as those in the pelagic zone. The results indicate that although the pelagic zone of the lake was net autotrophic $(\mathrm{P}: \mathrm{R}=2.46)$ based on annual cycles, total primary production to respiration (pelagic zone + sediments) was balanced, and the P:R ratio was 1.18 . Thus, potentially only a small part of pelagic primary production is exported and buried in the sediments. The whole lake ecosystem does not act as an effective atmospheric $\mathrm{CO}_{2}$ sink. The balanced primary production to respiration ratio in the open water zone of the lake indicated that littoral production was most probably decomposed or buried within the littoral zone.
\end{abstract}

Key words: Shallow lakes / primary production / respiration / decomposition / carbon cycling

\section{Introduction}

Although inland waters comprise a relatively small part of the Earth's surface, the high intensity of their carbon fluxes means that they contribute significantly to the carbon cycle (e.g., Cole et al., 1994; Cole et al., 2007). Differentiating between ecosystems which are sinks of atmospheric $\mathrm{CO}_{2}$ and ecosystems, which emit $\mathrm{CO}_{2}$ into the atmosphere is crucial to the understanding of the carbon budget of the biosphere (e.g., Cole et al., 2007).

Studies on the primary production-to-respiration ratio ( $P: R$ ratio) in the pelagic zones of lakes reveal that $P: R$ tends to increase with trophic levels in water bodies, thus oligotrophic waters are generally net heterotrophic with $\mathrm{P}<\mathrm{R}$, whereas pelagic zones of eutrophic waters are usually net autotrophic with $\mathrm{P}>\mathrm{R}$ (del Giorgio and Peters, 1994; Duarte and Agusti, 1998; Roberts and Howarth, 2006). Recent evidence indicates that, with the exception of some eutrophic water bodies, lakes are most often net sources of $\mathrm{CO}_{2}$ to the atmosphere, regardless of their trophy (Cole et al., 1994, 2007) because, in addition to internal ecosystem primary production, they probably also respire organic carbon derived from allochthonous inputs, e.g., riverine/groundwater and littoral zones (Cole et al., 1994, 2007; Kortelainen et al., 2006).

\footnotetext{
*Corresponding author: wielgatm@wp.pl
}

Most shallow lakes are subject to contrasting processes. They are often nutrient-rich and therefore exhibit high internal primary production and are thus net autotrophic. However, at the same time, sediment resuspension may reduce light availability in the water column (Scheffer, 2004) and heterotrophic processes increase relative to autotrophic ones, as most of the P-to- $\mathrm{R}$ ratio is driven by changes in primary production rates (e.g., Roberts and Howarth, 2006; Staehr et al., 2010). Additionally, shallow lakes most often receive high inputs of organic matter from the littoral zone and input of allochthonous organic matter from the drainage area. These inputs may lead to net heterotrophy even in productive ecosystems (e.g., Staehr et al., 2010). Respiration rates of surface sediments in shallow lakes are typically higher than in deep lakes. This is the result of weaker oxygen and temperature gradients between the pelagic zone and sediments as compared with those in stratified lakes, and much stronger sediment-water exchange that occurs because of frequent sediment resuspension that results in higher substrate quality and/or higher substrate supply to the sediments (den Heyer and Kalff, 1998). Some shallow lakes also tend to have high benthic primary production (at least those that are oligo-mesotrophic with high water transparency), contributing with high-quality substrate that fuels sediment respiration (SR) (e.g., Ask et al., 2009; Ask et al., 2012). In general, 
Table 1. General characteristics of Lake Gardno.

\begin{tabular}{|c|c|c|}
\hline$\overline{\text { Parameter }}$ & Value & Source \\
\hline Total surface area $\left(\mathrm{km}^{2}\right)$ & 24.68 & Balicki (1981) \\
\hline Maximum depth (m) & 2.6 & Balicki (1981) \\
\hline Mean depth (m) & 1.2 & Balicki (1981) \\
\hline Lake area covered by emergent macrophytes $(\%)$ & 4.0 & Trojanowski (2003a) \\
\hline Ntot (annual average) $\left({\left.\mathrm{g} \mathrm{N} . \mathrm{m}^{-3}\right)}^{-3}\right.$ & 1.411 & Jarosiewicz (2009) \\
\hline Ptot (annual average) (g P.m $\left.{ }^{-3}\right)$ & 0.176 & Jarosiewicz (2009) \\
\hline Light extinction coefficient $\left(\mathrm{m}^{-1}\right)$ & $2.8-11.7$ & Wielgat-Rychert et al. (2015) \\
\hline
\end{tabular}

sediment burial increases with lake productivity (Kortelainen et al., 2004). Pace and Prairie (2005) suggested that long-term carbon burial in stratified lakes is expected to be higher in more productive ecosystems in which a higher percentage of organic matter is buried in the sediments than in lakes with low productivity. But in shallow lakes, large portions of the organic matter, even in the most productive ones, are respired and might not be buried (e.g., Giziński et al., 1997). Thus, sediment respiration can shift shallow lakes toward net heterotrophy.

In the present study, we examined the major carbon fluxes of Lake Gardno in order to establish to what extent organic matter produced in this relatively large, shallow, polymictic lake can be decomposed within the lake ecosystem, and whether the whole system of this eutrophic lake can be a potential sink of $\mathrm{CO}_{2}$. We compared the measured values of gross primary production (GPP) and gross surface sediment primary production (SP) against total pelagic community respiration (PR) and sediment respiration (SR) values, all of which were measured with the oxygen method. Because time lags between primary production and decomposition processes are possible, we analyzed a long data set of measurements (2006-2011). To determine the significance of pelagic and benthic metabolism for the entire carbon budget of this shallow lake, we compared our open water measurements with the overall budget of the lake (input and output sources) based on measurements and data available in the literature.

\section{Lake Gardno}

Lake Gardno is located in the northern part of Poland $\left(54^{\circ} 39^{\prime} \mathrm{N}, 17^{\circ} 07^{\prime} \mathrm{E}\right)$ and it is one of the largest among a series of lakes located on the southern Baltic Sea coast. This is a shallow, turbid and polymictic lake (Table 1) because of its pan-shaped bottom and the large surface area that is exposed to winds from the sea (e.g., Balicki, 1981; Cieśliński, 2013). Shoreline development of the lake, that is the ratio of lake perimeter-to-the perimeter of a circle of an identical area, is close to 1 . It is a flow-through lake connected with the sea (Fig. 1). About $90 \%$ of the riverine inflow is discharged by the Łupawa River (Jędrasik and Cyberski, 2000); the average annual freshwater residence time is about 40 days. The lake is directly connected to the Baltic Sea by a channel, making it partly brackish. The Baltic Sea is non-tidal, so seawater intrusions occur on an irregular basis depending on wind

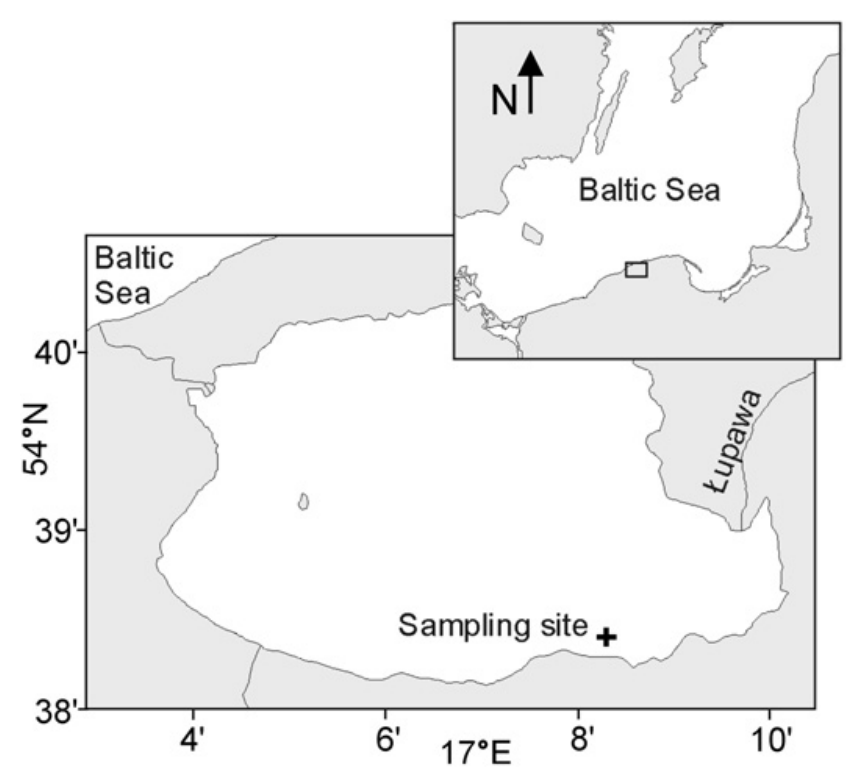

Fig. 1. Location of the measurement site in Lake Gardno.

speed and direction, and freshwater inflow (Balicki, 1981; Jędrasik and Cyberski, 2000; Cieśliński, 2013). The seawater inflow forms no vertical salinity gradient, only a horizontal gradient in the lake waters as is described in more detail by Cieśliński (2013). The salinity in the center of the lake measured in the present study was about 0.66 PSU as compared with the surface salinity of the southern Baltic Sea coast, which is about 7.5 PSU. The lake is classified as eutrophic (Wetzel, 2001; see Table 1).

\section{Material and methods}

Measurements were conducted offshore (Fig. 1), at an open water area where processes are representative of a majority of the lake's area as determined by Ficek and Wielgat-Rychert (2009). Gross phytoplankton primary production (GPP) and total planktonic community respiration (PR) were measured with the oxygen light and dark bottle method. The measurements were performed in $2006(n=14)$ and in $2007(n=9)$, and then until 2011 irregularly for a total of 40 measurements. In situ incubation lasted $24 \mathrm{~h}$ and was conducted to a depth of $1.2 \mathrm{~m}$. Since chlorophyll a profiles indicated that the water column was homogeneous (Ficek and Wielgat-Rychert, 2009), the water for incubation was only collected from the 
surface. In 2006, transparent and dark bottles (glass Winkler bottles with approximate volumes of $120 \mathrm{~mL}$ ) were incubated at depths of $0.0,0.3,0.6$ and $1.2 \mathrm{~m}$ in triplicate. Starting from April 2007, transparent bottles in duplicate were incubated at $10 \mathrm{~cm}$ depth intervals, to a depth of $0.6 \mathrm{~m}$, and at $20 \mathrm{~cm}$ intervals to a depth of $1.2 \mathrm{~m}$. After ten initial PR measurements, the number of PR bottles was reduced to four for the entire profile because no differences along the vertical profile were noted (see Wielgat-Rychert et al., 2010).

Benthic oxygen consumption/production was determined as the rate of oxygen decline in the enclosed water overlying the sediment. Benthic primary production and respiration were measured with duplicate dark and duplicate transparent benthic chambers (volume, $1.5 \mathrm{dm}^{-3}$; surface, $0.015 \mathrm{~m}^{-2}$ ) that were deployed manually over the sediment surface. The water for the oxygen measurements was siphoned from the benthic chambers with a gentle peristaltic pump. In situ incubation lasted for $24 \mathrm{~h}$ (with the exception of some respiration incubations in summer which lasted $2 \mathrm{~h}$ or $4 \mathrm{~h}$ and were recalculated to $24 \mathrm{~h}$ periods). Benthic primary production (SP) was measured at a depth of $0.6 \mathrm{~cm}$ only on five occasions in 2007 and 2008 (see Table 2). A sampling site that was shallower than $1.2 \mathrm{~m}$ was chosen in order to measure higher values than those measured at a depth of $1.2 \mathrm{~m}$ and to avoid problems with the resolution of the oxygen method. SP was calculated as a difference in oxygen concentration at the end of incubation between the transparent and dark benthic chambers. This value was corrected for primary production in the water by the parallel incubation of water confined in two transparent bottles. Benthic respiration (SR) was measured from 2007 to 2011. SR measurements were conducted at depths of 0.6 $\mathrm{m}(n=7), 0.9 \mathrm{~m}(n=5)$ and $1.2 \mathrm{~m}$ at the same location as the pelagic measurements $(n=13)$. Respiration in chambers was corrected for respiration in the water by the parallel incubation of water confined in two dark bottles. The sum of pelagic zone respiration (PR) and benthic respiration (SR) was assumed to be total lake open water respiration (TR). When only PR was measured, SR was calculated from total suspended matter (TSM) content with use of a model calculated in the "Results" section.

All oxygen measurements were conducted with the standard Winkler technique and a Schott Titroline Basic burette. Measurements were begun in the field, where a manganous sulfate and sodium hydroxide-potassium iodite mixture was added to the bottles to stop biological processes. Depth-integrated GPP and PR were calculated assuming a linear interpolation between successive measurements to a depth of $1.2 \mathrm{~m}$. The production and consumption of oxygen were transformed into carbon units $\left(\mathrm{mg} \mathrm{C} \cdot \mathrm{m}^{-2} \cdot \mathrm{d}^{-1}\right)$ with the photosynthetic quotient, $\mathrm{PQ}=1.2$ and the respiratory quotient, $\mathrm{RQ}=1.0$, which are the most typical values used for lakes (Wetzel and Likens, 1991). The standard deviation of these measurements is presented in Wielgat-Rychert et al. (2010).

In addition to GPP and PR measurements, temperature, Secchi depth visibility, nutrient concentrations, TSM content, and conductivity were measured in the surface water layer. Chlorophyll a concentrations were measured according to the standard spectrophotometric method with acetone extraction without correction for phaeopigments (Jeffrey and Humphrey, 1975). To determine the TSM, a known volume of water was filtered through preweighed Whatman GF/F filters, which were then weighed again after drying at $60^{\circ} \mathrm{C}$ to a constant weight. Photosynthetically active radiation (PAR) measurements were obtained from the Meteorological Station at the Pomeranian Academy in Słupsk, about $30 \mathrm{~km}$ from Lake Gardno. The underwater light fields (Table 1) were measured with a Satatlantic spectroradiometer (Wielgat-Rychert et al., 2015).

Sources and sinks of carbon to the pelagic waters of the lake not measured in this study were estimated on the basis of literature data. These included data on primary production of submerged and emergent macrophytes dominated by Phragmites species (see Table 3 below). This information was estimated on the basis of data from various water bodies in eastern Europe. Primary production was estimated as a seasonal maximum biomass. In the case of emergent macrophytes, only the aboveground biomass was considered as the principle possible source of organic carbon to pelagic waters. The $\mathrm{P} / \mathrm{B}$ rate for Phragmites was estimated at 1 after Gessner et al. (1996). Riverine input and outflow were estimated on the basis of water inflow/outflow and total organic carbon concentrations in water. The outflow was not corrected for marine water inflow. Methane emissions were estimated on the basis of literature data. Finally, all measured rates were averaged to obtain one value expressed in $\mathrm{mg} \mathrm{C} \cdot \mathrm{m}^{-2} \cdot \mathrm{d}^{-1}$. Estimated annual rates were also converted into the same unit (see Table 4 below).

Statistical analyses were performed with Statistica 10 (Statsoft).

\section{Results}

\section{Environmental conditions}

During the measurement period, the water temperature ranged from 2 to $24.5^{\circ} \mathrm{C}$, and PAR was within the range of $661-12795 \mathrm{~kJ} \cdot \mathrm{m}^{-2} \cdot \mathrm{d}^{-1}$. Figure 2(A) presents data from the period 2006 to 2011 . The water temperature maximum was noted in mid-July, which was later than the maximum PAR in about mid-June. Additionally, the water temperature curve was not symmetrical to its maximum; in the second half of the year, the water temperature was higher than in the first half. Low PAR values were noted in late fall, starting from October.

The chlorophyll a $(n=40)$ and TSM content in the water revealed no regular seasonal patterns during the vegetative season, and no clear water phase was observed, like in other shallow water bodies (Fig. 2(B)). Chlorophyll $\mathrm{a}$ and TSM values were high throughout the year including some winter days, which is a pattern that has been observed in shallow water bodies (Scheffer, 2004). TSM and 


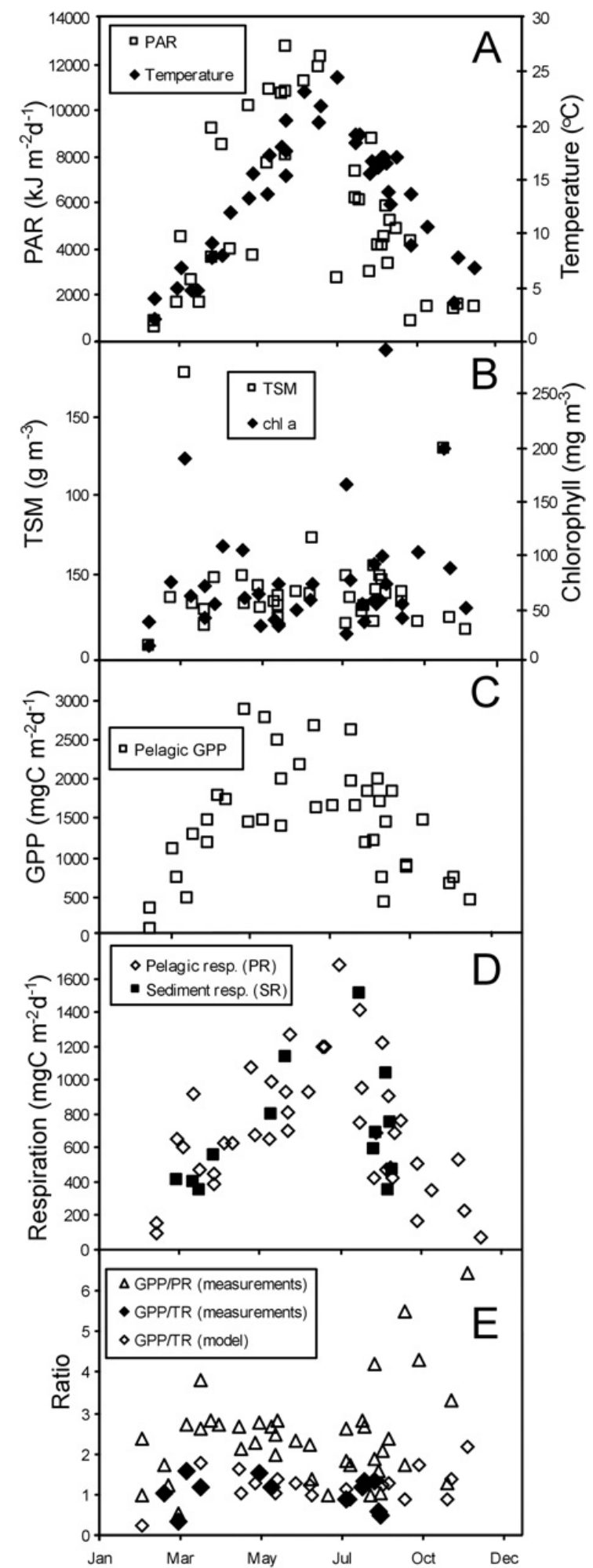

Fig. 2. (A) Seasonal changes of temperature, PAR and (B) chlorophyll, TSM concentrations (after Ficek and WielgatRychert 2009; Wielgat-Rychert et al. 2010). (C) Seasonal changes in pelagic GPP and (D) respiration values. (E) Seasonal GPP-to-PR ratio (pelagic zone) and GPP-to-TR ratio (sediment + pelagic) - measurements and data calculated with the model. Data were pooled from all measurement years (20062011) to show seasonal trends. chlorophyll a content in water were correlated $(n=35$, $\left.R^{2}=0.61, P<0.0001\right)$. The highest values of chlorophyll a and TSM concentrations in the water were associated with strong winds (see also Wielgat-Rychert et al., 2010).

\section{Primary production and respiration in the pelagic zone}

Daily GPP values $(n=40)$ calculated for the water column (1.2 $\mathrm{m}$ deep) ranged from 92 to $3627 \mathrm{mg}$ C.m ${ }^{-2} \cdot \mathrm{d}^{-1}$ (Fig. 2(C)). The maximum apparent volumetric photosynthetic rate per unit of chlorophyll a (assimilation number, $\mathrm{AN}$ ) was estimated for the 2007-2011 period when incubation in the surface layers was conducted at $10 \mathrm{~cm}$ depth increments (see "Material and Methods" section). AN values were recalculated from daily measurements of GPP, and these exhibited seasonal changes with maximum values in June of $8 \mathrm{mg}$ C.mg.Chl ${ }^{-1} \cdot \mathrm{m}^{-3} \cdot \mathrm{h}^{-1}$ and minimum values in November of $0.8 \mathrm{mg}$ C.mg.Chl ${ }^{-1} . \mathrm{m}^{-3} \cdot \mathrm{h}^{-1}$, which were similar in range to the values for shallow, turbid lakes and estuaries reported by Meyercordt et al. (1999), among others. GPP was not correlated to nutrient concentrations, but was correlated to light and temperature, which indicates that Lake Gardno can be classified as a light-limited system (see also Wielgat-Rychert et al., 2010).

Daily PR values $(n=40)$ ranged from 73 to $1680 \mathrm{mg} \mathrm{C} \cdot \mathrm{m}^{-2} \cdot \mathrm{d}^{-1}$ (Fig. 2(D)), and PR was correlated with temperature. In addition, PR, but not GPP, was positively correlated to TSM content; however, no correlation between PR and chlorophyll a was noted (Wielgat-Rychert et al., 2010). Each year, PR values were higher in spring (Fig. 2(D)) than in the fall at the same temperature range, but the difference was not statistically significant ( $t$-test, $P=0.08$ ).

\section{Benthic processes}

\section{Sediment primary production}

Benthic primary production measured at a depth of 0.6 $\mathrm{m}$ in Lake Gardno ranged from 172 to 0 (measured as values below zero) $\mathrm{mg}$ C.m $\mathrm{m}^{-2} \cdot \mathrm{d}^{-1}(n=5)$ as given in Table 2. Negative values, measured on one occasion, represent higher respiration recorded in transparent benthic chambers than in dark ones. Benthic primary production was very low and corresponded to about $5 \%$ of the areal pelagic primary production (GPP) measured during the same days (Table 2). Because only five measurements were carried out, a seasonal trend cannot be observed. Pelagic GPP in the 0.5-0.6 m layer was lower or similar in range to the GPP measured in benthic chambers at a depth of $0.6 \mathrm{~m}$.

\section{Sediment respiration}

Benthic respiration at a depth of $1.2 \mathrm{~m}$ in Lake Gardno ranged from 348 to $1504 \mathrm{mg} \mathrm{C} \cdot \mathrm{m}^{-2} \cdot \mathrm{d}^{-1}(n=13)$. It was 
Table 2. Benthic primary production (SP) at a depth of $0.6 \mathrm{~m}$ compared with areal pelagic primary production (GPP) at the same depth.

\begin{tabular}{|c|c|c|c|c|c|}
\hline & March 2007 & April 2007 & May 2007 & September 2008 & September 2008 \\
\hline Compensation depth (m) & $>1.2$ & $>1.2$ & $>1.2$ & 1.1 & 0.7 \\
\hline Benthic primary production (SP) $\left(\mathrm{mg} \mathrm{C} \cdot \mathrm{m}^{-2} \cdot \mathrm{d}^{-1}\right)$ & 35 & 53 & 144 & -65 & 172 \\
\hline Pelagic GPP $\left(\mathrm{mg} \mathrm{C} \cdot \mathrm{m}^{-2} \cdot \mathrm{d}^{-1}\right)$ & 743 & 1468 & 1442 & 2007 & 1702 \\
\hline$\%$ of areal pelagic GPP in the $0.5-0.6 \mathrm{~m}$ layer & 7.3 & 11 & 9 & 8 & 7 \\
\hline$\%$ of areal SP expressed as $\%$ areal pelagic GPP & 4.7 & 3.6 & 10 & -3.2 & 10 \\
\hline Mean $\%$ of areal SP & 5 & & & & \\
\hline
\end{tabular}

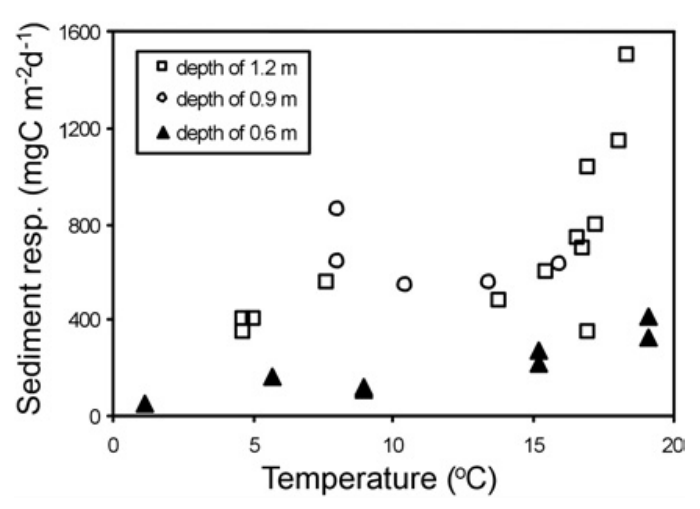

Fig. 3. Benthic respiration at different depths as a function of temperature.

in the range of pelagic respiration as shown in Figure 2(D). Figure 3 also presents values measured at other depths. No seasonal trends or water temperature dependencies were observed. As mentioned above, PR was correlated to TSM in water. The fraction of SR to total respiration $(\mathrm{TR}=\mathrm{PR}+\mathrm{SR})$ was inversely correlated to TSM content in water, with the exception of extreme TSM values (Fig. 4; \% respiration in sediments $=0.86 \times$ $\operatorname{EXP}(-0.016 \times \mathrm{TSM}) ; P=0.02)$. SR was not measured as often as PR. Whenever SR values were not measured, they were calculated with this model from TSM concentration and PR. Measurements of respiration conducted concurrently in the sediments and the pelagic zone indicated that SR accounted for $50 \%$ of TR, on average.

\section{Seasonal pattern of open water lake metabolism}

Comparison of measurements of pelagic GPP and PR indicates that the pelagic zone of Lake Gardno was net autotrophic with an average GPP-to-PR ratio of 2.42 at a range of $0.53-6.45$. Intensive primary production was recognized as the oxygen oversaturation of surface waters at an average of $115 \% \quad(n=40)$; however, primary production rates dropped very steeply with depth. The GPP-to-TR ratio was much lower than that of GPP to PR at an average annual value of $1.09(n=13)$ at a range of $0.37-1.57$, whereas the GPP-to-TR ratio calculated from the modeled TR values was 1.18 at a range of $0.23-2.20$. The seasonal pattern of GPP to the modeled TR ratio resembled the measured GPP-to-PR ratio with higher values in spring and in fall (Fig. 2(E)).

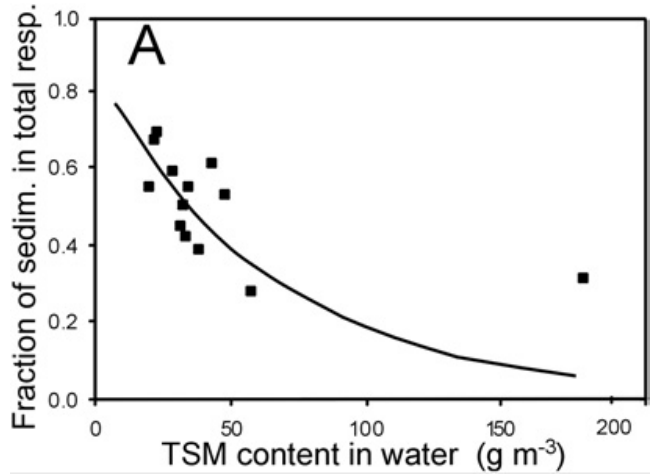

Fig. 4. Fraction of sediment respiration $\left(m g C \cdot m^{-2} \cdot d^{-1}\right)$ to the sum of (sediment + pelagic) respiration expressed as a function of TSM content in water.

\section{Sources and sinks not measured in this study}

Below, the importance of major outer fluxes of organic carbon to the lake pelagic waters was estimated for comparison with the open water zone processes. To the authors' knowledge, no data exist on the spatial coverage by submerged macrophytes of the lake bottom. Table 3 presents information on macrophyte production used for estimations in Lake Gardno. In large coastal lagoons, which resemble Lake Gardno, submerged macrophyte production is relatively low, because the area covered by macrophytes is usually limited to a few percent of the bottom (Table 3). Our estimate of such production in Lake Gardno could be rounded to about $1-20 \mathrm{~g} \mathrm{C} . \mathrm{m}^{-2} \cdot \mathrm{yr}^{-1}$ (2.7-54 mg C. $\left.\mathrm{m}^{-2} \cdot \mathrm{d}^{-1}\right)$. Spatial coverage by standing macrophytes (helophytes) was assessed in Lake Gardno to be $4 \%$ of the total lake area and it took the form of a belt along the shoreline. This community was dominated by Phragmites sp. with Typha sp. and neither macrophyte biomass nor production was measured (Kraska, 2003). Taking into account shallow and large lagoons rather than deeper lakes, the estimated primary production in the reed belt in Lake Gardno could be rounded to about 50-59 g C. $\mathrm{m}^{-2} \cdot \mathrm{yr}^{-1}\left(136-160 \mathrm{mg} \mathrm{C} . \mathrm{m}^{-2} \cdot \mathrm{d}^{-1}\right)$ if primary production in the littoral zone was recalculated for the total surface area of Lake Gardno (Table 3). Because of the lack of extensive data for comparison, respiration in the littoral zone was not estimated. We assumed that periphyton primary production was similar in range to that for the Szczecin Lagoon $\left(60 \mathrm{mg}\right.$ C.m $\left.\mathrm{m}^{-2} . \mathrm{d}^{-1}\right)$ estimated by Wolnomiejski and Witek (2013). 


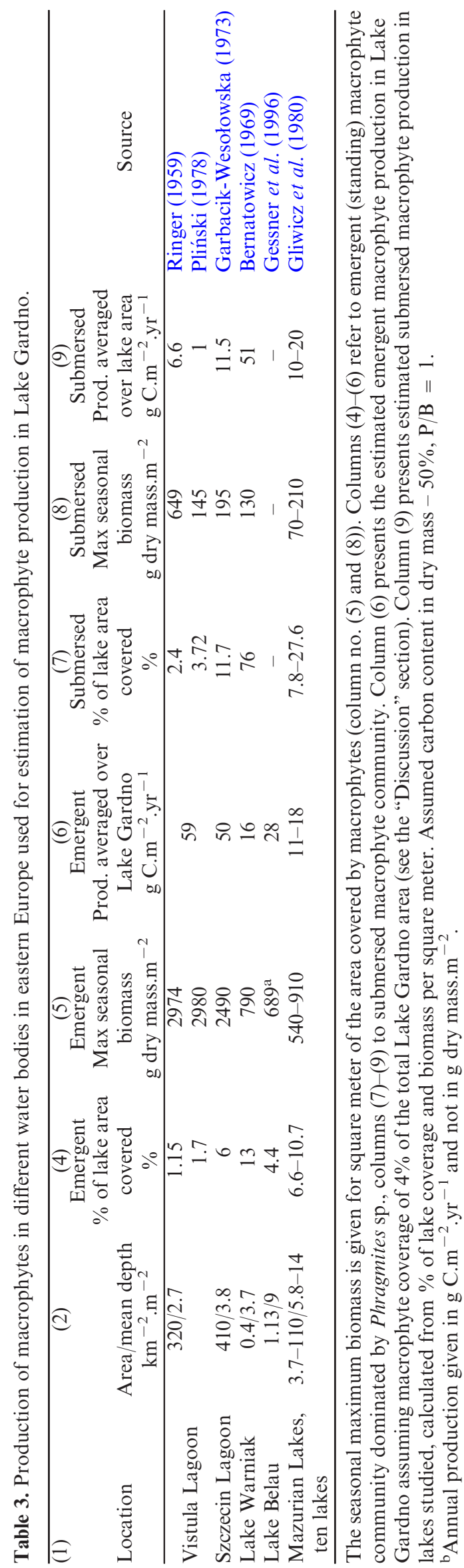

The average annual freshwater inflow, including water pumped into the lake from the polder areas of the immediate drainage basin, was about $9 \mathrm{~m}^{-3} \cdot \mathrm{s}^{-1}$ (Jędrasik and Cyberski, 2000). Taking this value into account and the average total organic carbon concentration in Lupawa River waters ( $7.6 \mathrm{mg} \mathrm{C.} \mathrm{dm}^{-3}$; Gorzeń and Załupka, 2009-2010), the annual riverine organic carbon load was 2200 metric tons in the 2008-2009 period. If these values are recalculated to the lake surface area, the average input into Lake Gardno is about $244 \mathrm{mg} \mathrm{C} . \mathrm{m}^{-2} \cdot \mathrm{d}^{-1}$. The outflow load was calculated with the average value of 10.4 $\mathrm{mg} \mathrm{C} . \mathrm{dm}^{-3}$ for the 2008-2009 period (Gorzeń and Załupka 2009; 2010) and amounted to about $331 \mathrm{mg}$ C.m ${ }^{-2}$ of the lake area per day (Table 4). Inflow and outflow values were calculated from total organic carbon (dissolved and particulate). The seawater inflow estimated by Balicki (1981) was only $4.3 \%$ of the total inflow into the lake and the ground water inflow was about $8 \%$ of total water inflow. These two minor carbon sources were not estimated here. The atmospheric water input estimated by Balicki (1981) was $4.4 \%$ of the total water and because it was rather low, this input was not included in the budget.

Methane is formed during the anaerobic decomposition of organic remains in lake bottoms, but its emission from aquatic systems is relatively small compared to $\mathrm{CO}_{2}$ (Cole et al., 2007). The values reported by Wetzel (2001) were at a range of $1.0-10.4 \mathrm{mg} \mathrm{C} \cdot \mathrm{m}^{-2} \cdot \mathrm{d}^{-1}$. According to a review by Walter Anthony et al. (2010), seasonal averages of such emissions in the temperate zone ranged from 2.7 to $768 \mathrm{mg} \mathrm{CH} 4 \cdot \mathrm{m}^{-2} \cdot \mathrm{d}^{-1}$ (Table 4). However, at 10 of 17 research sites these authors studied, it was lower than $150 \mathrm{mg} \mathrm{CH} \cdot \mathrm{m}^{-2} \cdot \mathrm{d}^{-1}$.

\section{Discussion}

\section{Pelagic processes}

In eutrophic water bodies, pelagic primary production usually exceeds respiration, whereas in unproductive systems, respiration generally exceeds primary production (del Giorgio and Peters, 1994; Duarte and Agusti, 1998; Roberts and Howarth, 2006). Rates of processes measured in Lake Gardno were within the range measured in eutrophic water bodies (e.g., Wetzel, 2001). The average GPP rate in Lake Gardno was $1511 \mathrm{mg} \mathrm{C} . \mathrm{m}^{-2} \cdot \mathrm{d}^{-1}$ to a depth of $1.2 \mathrm{~m}$. This is high enough for aquatic ecosystems to become net autotrophic according to Duarte and Agusti (1998) and, on annual basis, the pelagic zone of Lake Gardno was net autotrophic with an average GPP-to-PR ratio of 2.46. The impact of the food web structure on the high pelagic P-to- $\mathrm{R}$ ratio was not studied in the present work; nevertheless, it could be mentioned that cladocerans that can control phytoplankton biomass were present in Lake Gardno (as discussed by Rychert et al., 2012) despite marine water inclusions (according to Jeppesen et al. (1994) at a salinity exceeding 2 PSU cladocerans are excluded). However, the clear-water phase was not observed, possibly because in turbid waters overall 
Table 4. Production and respiration measured in the open water zone of Lake Gardno compared with estimation of other major carbon fluxes to/from the open water zone.

\begin{tabular}{|c|c|c|}
\hline & $\begin{array}{l}\text { Production/input } \\
\left(\mathrm{mg} \mathrm{C}^{-2} \cdot \mathrm{d}^{-1}\right)\end{array}$ & $\begin{array}{l}\left.\text { Respiration } / \text { output }^{\text {Rg C.m }}{ }^{-2} \cdot{ }^{-1}\right)\end{array}$ \\
\hline \multicolumn{3}{|l|}{ MEASURED FLUXES } \\
\hline Pelagic zone (gross prod.) & 1511 & 704 \\
\hline Benthic zone (gross prod.) & $<76$ & 740 \\
\hline TOTAL & 1587 & 1444 \\
\hline Net ecosystem production & 143 & \\
\hline \multicolumn{3}{|l|}{ ESTIMATED FLUXES } \\
\hline Riverine (DOC + POC) inflow/outflow & 244 & 331 \\
\hline Submersed macrophytes (net prod.) & $2.7-54$ & Not estimated \\
\hline Standing macrophytes (net prod.) & $135-160$ & Not estimated \\
\hline Periphyton & 60 & - \\
\hline Methane emissions & - & $2.7-768$ \\
\hline
\end{tabular}

Sediment primary production was calculated at a maximum of 5\% of areal GPP (see Table 2). Macrophyte production from Table 3 . For other data calculation see the "Discussion" section.

predation pressure exerted over high phytoplankton biomass can be much less pronounced than in clear waters (e.g., Muylaert et al. 2006).

\section{Sediment versus pelagic respiration}

Although the pelagic zone of Lake Gardno was net autotrophic, this high GPP/PR ratio decreased significantly when SR was taken into account (GPP/ $\mathrm{TR}=1.18$ ), indicating a significant role of sediment decomposition of organic matter produced in the euphotic zone. Other authors also found SR to be one of the primary factors contributing to excess respiration in lakes (e.g., Kortelainen et al., 2006). The respiration of sediment bacteria in lakes with aerobic conditions is primarily correlated with oxygen conditions, temperature and organic matter content (e.g., Wetzel, 2001). The lake water was well mixed and well oxygenated down to the bottom during sampling, and anoxic conditions at the sediment surface were not observed, as was the case in other studies (Trojanowski, 2003b). The water temperature at the sediment surface did not differ substantially from that in the pelagic zone as indicated by temperature profiles (Ficek and Wielgat-Rychert, 2009). When the PR dependence on temperature was compared with that of SR at a depth of $1.2 \mathrm{~m}$, they did not differ significantly (Fisher's $z$-transformation, two-tailed test, $P=0.8$ ). Thus, we conclude that the composition of organic matter in sediment surface layers did not differ substantially from that of the pelagic zone since exchange of organic matter between the pelagic zone and sediments has been observed frequently in other shallow lakes (e.g., Giziński et al., 1997). The fraction of SR in total respiration decreased with increase of TSM in water (Fig. 4). The minimum SR fraction value measured was $28 \%$ (at TSM $=58$ g.m ${ }^{-3}$ ), but similar values $(31 \%)$ were also measured at $\mathrm{TSM}=180 \mathrm{~g} \cdot \mathrm{m}^{-3}$. We interpreted this as an indication that an increase in TSM concentration over $50 \mathrm{~g} . \mathrm{m}^{-3}$ did not decrease SR any further, that is, below about $30 \%$. Thus, regardless of the mixing intensity, at least about
$30 \%$ of total respiration always occurred at the sediment surface, probably because at high TSM concentrations in pelagic water, TSM contained more inorganic matter (IM). Single IM measurements indicated that TSM concentrations up to 30 g.m ${ }^{-3}$ contained almost exclusively organic matter, but values of TSM from about 50 to maximum 180 g.m ${ }^{-3}$ contained almost $50 \%$ IM.

\section{Sediment versus pelagic primary production}

In shallow, clear-water lakes, SP can be high and balance SR (e.g., Ask et al., 2009); however in turbid lakes, $\mathrm{SP}$ is expected to be limited because of high PAR attenuation in the water (e.g., Kirk, 1994). Our studies indicated that pelagic primary production dropped with depth very steeply, to an average of $3.9 \%$ in the bottom layer (in the 2007-2011 period). Light limitation might also explain why primary production in sediment was found to be very low, contributing only about $5 \%$ to the areal pelagic production in Lake Gardno (Table 2). We would expect a further decrease of this rate at a depth of $1.2 \mathrm{~m}$ compared with $0.6 \mathrm{~m}$ due to light limitation. Most benthic primary production in Lake Gardno occurs close to the average depth of the lake at about $1.2 \mathrm{~m}$ because Lake Gardno has a relatively flat bottom. Only $3.8 \%$ of the lake bottom is deeper than $2 \mathrm{~m}$ and about $19 \%$ is shallower than $1 \mathrm{~m}$ (Balicki, 1981). It is likely that SP rates were not representative of the entire lake surface sediments because the most shallow areas along the shore of Lake Gardno probably belonged to the abrasive zone "erosion bottoms" (as discussed below). Such areas contain less organic matter (and thus phytoplankton cells) deposited at the surface of the sediment compared with deeper areas. Thus, the areal primary production rate at $0.6 \mathrm{~m}$ was probably lower compared with deeper "accumulation areas". In summary, the SP to respiration ratio was very low and benthic primary production was not an important source of organic matter to the lake. In shallow, eutrophic lakes phytoplankton is expected to be responsible for most primary production (e.g., nearly $100 \%$ in shallow Danish 
lakes with TP $>0.1 \mathrm{mg}$ P. $\mathrm{dm}^{-3}$, as measured by Vadeboncoeur et al., 2003).

\section{Spatial heterogeneity}

Measurements conducted in the present study were conducted at one location only. However, spatial heterogeneity within a lake is an important problem in ecosystem metabolism estimation. Respiration in littoral zone sediments frequently exceeds that measured in the benthic (profundal) zone (den Heyer and Kalff, 1998; Wetzel, 2001; Van de Bogert et al., 2007). Van de Bogert et al. (2007) have shown several fold differences in metabolism estimates from site to site along transects from the shore to the center of the lake. According to the authors, an estimate based on a single, central location on average underestimated whole lake values of primary production and respiration. However, when wind speeds were high, metabolism estimates were quite similar between locations (Van de Bogert et al., 2007). Lake Gardno is prone to mixing due to its large area, pan-shaped bottom and exposure to winds from the Baltic Sea. This was demonstrated by earlier studies (Trojanowski, 2003b; Ficek and Wielgat-Rychert, 2009; Cieśliński, 2013).

No measurements in the littoral zone were carried out in the present study, but SR measured at different depths and at different dates was evaluated to discuss the possible importance of the impact of the littoral zone. No influence of the littoral zone in shallow measurement points was observed. Instead, when SR dependences on temperature from the different depths of $0.6,0.9$ and $1.2 \mathrm{~m}$ were compared (Fig. 3), for the same range of TSM content in water, values measured in water at the depth of $0.6 \mathrm{~m}$ were lower than those at $0.9 \mathrm{~m}$ (ANOVA, $P=0.001$, post hoc Tukey's test, $P=0.02$ ) and $1.2 \mathrm{~m}$ (post hoc Tukey's test, $P=0.001)$. We interpreted this as an indication that the sediments at a depth of $0.6 \mathrm{~m}$ belonged to the abrasive zone "erosion bottoms", where lower organic matter content lowered the areal respiration rate as compared with "accumulation areas", even though, in general, in a very shallow lake, wave action is effective over the entire lake bottom and there are no areas where fine material can accumulate permanently (Bengtsson and Hellstrom, 1992). Still, short-term deposition occurs in deeper areas where most organic material reaching the open water zone of the lake is decomposed. Shallow "erosion bottoms" with lower respiration are of limited importance in Lake Gardno where only $19 \%$ of a lake area is shallower than $1 \mathrm{~m}$ (Balicki, 1981).

\section{Seasonal changes}

In early spring in temperate climates, pelagic primary production typically exceeds respiration because photosynthesis is less inhibited by low temperatures than respiration is (del Giorgio and Peters, 1994). This was also noted in Lake Gardno beginning at the end of March
(Fig. 2(E)). The lower GPP-to-PR ratio noted in August resulted from the high $\mathrm{PR}$ rates at the highest water temperatures compared with GPP rates that had already started to decrease following the decrease in daily irradiance (see Fig. 2(A)). Seasonal patterns in some shallow coastal lagoons often exhibit a shift from net autotrophy in spring and summer to net heterotrophy in the fall (e.g., Dubois et al., 2009); however, in fall, Lake Gardno was a net autotrophic system. During late fall, GPP-to-PR ratios were again elevated (Fig. 2(E)), because GPP rates were relatively high in comparison with PR rates that decreased quite rapidly (Fig. 2(C) and (D)). Decreases in TSM and PR during the fall might have been a result of increases in sea water inflows during the second half of the year, which resulted in lower organic matter content in lake water as a substrate for bacterial respiration. The limited number of measurements did not permit us to draw conclusions about winter metabolism.

\section{Limitations of the oxygen method}

The oxygen method is not a direct measurement of carbon fluxes. The most important assumed values are the $\mathrm{PQ}$, which is a molar ratio of oxygen-to-carbon production $\left(\mathrm{O}_{2} / \mathrm{CO}_{2}\right)$, and the RQ, which is the molar ratio of carbon-to-oxygen respiration $\left(\mathrm{CO}_{2} / \mathrm{O}_{2}\right)$. Theoretically estimated PQ values ranged from 1.08 to 1.40 , and RQ ranged from 0.67 to 0.93 (Laws, 1991; Williams and Robertson, 1991). In the present calculations, a PQ value of 1.2 and an RQ value of 1 were used as is recommended for lakes by Wetzel and Likens (1991). The value of PQ and RQ used in the calculation significantly influenced the $P: R$ ratio calculated for the ecosystem. Applying $\mathrm{RQ}=0.8$, which more closely represents the biochemical composition of a typical cell (e.g., Williams and Robertson, 1991; Wetzel, 2001), increases the GPP/PR and GPP/TR ratios by $25 \%$. When the values used were $\mathrm{PQ}=1.0$ and $\mathrm{RQ}=1.0\left(\mathrm{~mol} \mathrm{O}_{2}\right.$ to $\left.\mathrm{mol} \mathrm{C}\right)$, the ratio increased by $20 \%$.

\section{Carbon budget in Lake Gardno}

Table 4 presents the summary of measured and estimated carbon fluxes in Lake Gardno. The pelagic zone phytoplankton primary production was the most important carbon sink of the lake ecosystem, whereas the SP rate was low. PR and SR were similar in range being the most important $\mathrm{CO}_{2}$ sources to the atmosphere. According to our measurements, open water zone net ecosystem production amounted to $143 \mathrm{mg} \mathrm{C} \cdot \mathrm{m}^{-3} \cdot \mathrm{d}^{-1}$. According to Pace and Prairie (2005), long-term carbon burial increases with lake productivity. However, high respiration rates, both in the pelagic zone and at the sediment surface, resulted in a rather balanced GPP-to-TR ratio in the open water area of the shallow Lake Gardno. Estimates indicated that outflowing water contained 
slightly more organic carbon than did riverine inflow; roughly about $87 \mathrm{mg} \mathrm{C} \cdot \mathrm{m}^{-3} \cdot \mathrm{d}^{-1}$.

\section{Sources and sinks of organic carbon not measured in this study}

Inputs into the open water zone of a lake from the littoral zone and allochthonous sources also fuel open water ecosystem metabolism (Wetzel, 1992, 2001; Gessner et al., 1996; den Heyer and Kalff, 1998; Pace and Prairie, 2005; Cole et al., 2007; Van de Bogert et al., 2007), as littoral zones are regarded the most productive areas of aquatic ecosystems (e.g., Wetzel, 1992; Reitner et al., 1999). In Lake Gardno, the maximum values of the net littoral primary production of standing macrophytes averaged over the lake area were similar in range to those of net pelagic zone primary production (Table 4), but because the littoral zone fluxes in the budget were based only on estimates, it is difficult to formulate precise conclusions about this influence. Due to the low level of shoreline development of Lake Gardno (Table 1) and the size of the lake, estimated littoral inputs are probably of limited significance. Littoral areas are also very important sites for the degradation of organic matter (den Heyer and Kalff, 1998; Wetzel, 2001; Güde et al., 2004). Also, it has been shown that particulate organic matter produced there usually remains within the area of its production where it is accumulated and/or decomposed (Wetzel, 1992, 2001; Gessner et al., 1996). The balanced primary production to respiration ratio in the open water zone indicated that littoral primary production was most probably decomposed or buried in the littoral zone. Actually, the surface area of the lake was noted to be diminishing (Cieśliński 2013 and references therein).

If most of the lake bottom is covered by macrophytes, as in the case of Lake Warniak (Table 3), this source could be very important. However, the ratio of littoral to pelagic primary production is dependent on macrophyte spatial extension in comparison to the epilimnion area/volume (e.g., Gessner et al., 1996; Wetzel, 2001; Vadeboncoeur et al., 2003). According to Kraska (2003), the bottom of Lake Gardno is covered by submerged macrophytes to a rather limited extent because of the intensive sediment resuspension, which contributes to the low visibility of these eutrophic waters. We also noted this phenomenon and estimated this source to be of minor importance.

The total budget of organic carbon in any lake should also include anaerobic processes. Most authors indicate that methane emission from aquatic systems is relatively small compared with $\mathrm{CO}_{2}$ (Wetzel, 2001; Cole et al., 2007), but measured fluxes vary to a large extent (Table 4). Ebullition of $\mathrm{CH}_{4}$ is difficult to measure because bubbles occur sporadically and randomly across the surface of lakes and consequently $\mathrm{CH}_{4}$ emissions from lakes might be underestimated (Walter Anthony et al., 2010). Taking this into account, $\mathrm{CH}_{4}$ flux might impact the carbon budget of the open water zone more significantly.
Acknowledgements. The study was conducted within the statutory activities of the Pomeranian University in Słupsk (Poland), Project number 11.6.15.

\section{References}

Ask J., Karlsson J., Persson L., Ask P., Byström P. and Jansson M., 2009. Terrestrial organic matter and light penetration: effects on bacterial and primary production in lakes. Limnol. Oceanogr., 54, 2034-2040.

Ask J., Karlsson J. and Jansson M., 2012. Net ecosystem production in clear-water and brown-water lakes, Global Biogeochem. Cycles, 26, GB1017.

Balicki H., 1981. Hydrology outline of Gardno Lake. Wiadomosci. IMGW, 28, 91-98 (in Polish).

Bengtsson L. and Hellstrom T., 1992. Wind-induced resuspension in a small shallow lake. Hydrobiologia, 241, 163-172.

Bernatowicz S., 1969. Macrophytes in Lake Warniak and their chemical composition. Pol. J. Ecol., 17, 447-467.

Cieśliński R., 2013. Short-term changes in specific conductivity in Polish coastal lakes (Baltic Sea basin). Oceanologia, 55, 639-661.

Cole J.J., Caraco N.F., Kling G.W. and Kratz T.K., 1994. Carbon Dioxide Supersaturation in the Surface waters of Lakes. Science, 265, 1568-1570.

Cole J.J., Prairie Y.T., Caraco N.F., McDowell W.H., Tranvik L.J., Striegel R.G., Duarte C.M., Kortelainen P., Downing J.A., Middelburg J.J. and Melack J., 2007. Plumbing the global carbon cycle: integrating inland waters into the terrestrial carbon budget. Ecosystems, 10, 171-184.

del Giorgio P.A. and Peters R.H., 1994. Patterns in planktonic $P: R$ ratios in lakes: influence of lake trophy and dissolved organic carbon. Limnol. Oceanogr., 39, 772-787.

den Heyer C. and Kalff J., 1998. Organic matter mineralization rates in sediments: a within- and among-lake study. Limnol. Oceanogr., 43, 695-705.

Duarte C.M. and Agusti S., 1998. The $\mathrm{CO}_{2}$ balance of unproductive ecosystems. Science, 285, 234-236.

Dubois K., Carignan R. and Veizer J., 2009. Can pelagic net heterotrophy account for carbon fluxes from eastern Canadian lakes? Appl. Geochem., 24, 988-998.

Ficek D. and Wielgat-Rychert M., 2009. Spatial distribution and seasonal variation in chlorophyll concentrations in the coastal Lake Gardno (Poland). Oceanol. Hydrobiol. Stud., 38, 3-15. DOI 10.2478/v10009-009-0002-z

Garbacik-Wesołowska A., 1973. The macrophyte biomass in the Szczecin Lagoon. Symp. Naukowe w Świnoujściu, Wydawnictwo MIR, Gdynia, 81-86 (in Polish).

Gessner M.O., Schieferstein B., Muller U., Barkmann S. and Lenfers U.A., 1996. A partial budget of primary organic carbon flows in the littoral zone of a hardwater lake. Aquat. Bot., 55, 93-105.

Giziński A., Kentzer A. and Rejewski M., 1997. Why does Druzno Lake (Poland) still exist? On the conditions of the pond-type lake ecosystem sustainability. Hydrobiologia, 342/343, 297-304.

Gliwicz Z.M., Kowalczewski A., Ozimek T., Pieczyńska E., Prejs A., Prejs K. and Rybak J.I., 1980. An Assessment of the State of Eutrophication of the Great Mazurian Lakes, Wydawnicto Akcydensowe, Warsaw, 103 p. (in Polish). 
Gorzeń A. and Załupka A., 2009-2010. Water quality of the Słupia River at Charnowo, Lupawa et Smołdzino, Leba at Cecynowo in 2008-2009. WIOS Reports, Słupsk (in Polish).

Güde H., Teiber P., Rolinski S. and Sala M., 2004. Comparison of production and degradation of organic matter at a littoral site of the prealpine Lake Constance. Limnologica, 34, 117-123.

Jarosiewicz A., 2009. Seasonal changes of nutrient concentration in two shallow estuarine Lakes Gardno and Lebsko: comparison. Baltic Coast. Zone, 13, 121-133. Available online at: http://bcz.apsl.edu.pl/

Jędrasik J. and Cyberski J., 2000. The water exchange in estuarine lakes of the southern Baltic Sea as on the Gardno Lake example. Oceanol. Stud., 29, 43-66.

Jeffrey S.W. and Humphrey G.F., 1975. New spectrophotometric equation for determining chlorophyll a, b, c1 and c2. Biochem. Physiol. Pfl., 167, 194-204.

Jeppesen E., Søndergaard M., Kanstrup E., Petersen B., Eriksen R.B., Hammershøj M., Mortensen E., Jensen J.P. and Have A., 1994. Does the impact of nutrients on the biological structure and function of brackish and freshwater differ? Hydrobiologia, 275/276, 15-30.

Kirk J.T.O., 1994. Light and Photosynthesis in Aquatic Ecosystems, Cambridge University Press, Cambridge, 490 p.

Kortelainen P., Pajunen H., Rantakari M. and Saarnisto M., 2004. A large carbon pool and small sink in boreal Holocene lake sediments. Glob. Change Biol., 10, 1648-1653.

Kortelainen P., Rantakari M., Huttunen J.T., Mattsson T., Alm J., Juutinen S., Larmola T., Silvola J. and Martikainen P.J., 2006. Sediment respiration and lake trophic state are important predictors of large $\mathrm{CO}_{2}$ evasion from small boreal lakes. Glob. Change Biol., 12, 1554-1567.

Kraska M., 2003. The flora. In: Mudryk Z. (ed.), Lake Gardno, Pomeranian Pedagogical Academy in Słupsk, Słupsk, 93-98 (in Polish).

Laws E.A., 1991. Photosynthetic quotients, new production, net community production in the open ocean. Deep-Sea Res., 38, 143-167.

Meyercordt J., Gerbersdorf S. and Meyer-Reil L.-A., 1999. Significance of pelagic and benthic primary production in two shallow coastal lagoons of different degrees of eutrophication in the southern Baltic Sea. Aquat. Microb. Ecol., 20, 273-284.

Muylaert K., Declerck S., Van Wichelen J., De Meester L. and Vyverman W., 2006. An evaluation of the role of daphnids in controlling phytoplankton biomass in clear water versus turbid shallow lakes. Limnologica, 36, 69-78.

Pace M.L. and Prairie Y.T., 2005. Respiration in lakes. In: del Giorgio P.A. and Williams PJ.leB. (eds.), Respiration in Aquatic Systems, Oxford University Press, Oxford, 103-119.

Pliński M., Kreńska B. and Wnorowski T., 1978. Floristic relations and biomass of vascular plants in the Vistula Lagoon. Stud. Mater. Oceanol., 21, 161-196 (in Polish).

Reitner B., Herzig A. and Herndl G.J., 1999. Dynamics in bacterioplankton production in a shallow, temperate lake (Lake Neusiedl, Austria): evidence for dependence on macrophyte production rather than phytoplankton. Aquat. Microb. Ecol., 19, 245-254.
Ringer Z., 1959. Experiments aiming to classify the littoral flora biomass in the Vistula Firth on the basis of investigations carried on in 1955. Prace MIR, 10/A, 193-214 (in Polish).

Roberts B.J. and Howarth R.W., 2006. Nutrient and light availability regulate the relative contribution of autotrophs and heterotrophs to respiration in freshwater pelagic ecosystems. Limnol. Oceanogr., 51, 288-298.

Rychert K., Wielgat-Rychert M., Szczurowska D., Myszka M., Bochyńska M. and Krawiec K., 2012. The importance of Ciliates as a trophic link in Shallow, Brackish, and Eutrophic Lakes. Pol. J. Ecol., 60, 767-776.

Scheffer M., 2004. Ecology of Shallow Lakes, Kluwer Academic Publishers, Dordrecht, Boston, London, 357 p.

Staehr P.W., Sand-Jensen K., Raun A.L., Nilsson B. and Kidmose J., 2010. Drivers of metabolism and net heterotrophy in contrasting lakes. Limnol. Oceanogr., 55, 817-830.

Trojanowski J., 2003a. Location and general characteristic of lake. In: Mudryk Z. (ed.) Lake Gardno, Pomeranian Pedagogical Academy in Słupsk, Słupsk, 9-12 (in Polish).

Trojanowski J., 2003b. Hydrochemical characteristics. In: Mudryk Z. (ed.) Lake Gardno, Pomeranian Pedagogical Academy in Słupsk, Słupsk, 53-63 (in Polish).

Vadeboncoeur Y., Jeppesen E., Vander Zanden M.J., Schierup H.-H., Christoffersen K. and Lodge D.M., 2003. From Greenland to green lakes: cultural eutrophication and the loss of benthic pathways in lakes. Limnol. Oceanogr., 48, 1408-1418.

Van de Bogert M.C., Carpenter S.R., Cole J.J. and Pace M.L., 2007. Assessing pelagic and benthic metabolism using free water measurements. Limnol. Oceanogr. Methods, 5, $145-155$.

Walter Anthony K.M., Vas D.A., Brosius L., Chapin F.S. III, Zimov S.A. and Zhuang Q., 2010. Estimating methane emissions from northern lakes using icebubble surveys. Limnol. Oceanogr. Methods, 8, 592-609.

Wetzel R.G., 1992. Gradient-dominated ecosystems: sources and regulatory functions of dissolved organic matter in freshwater ecosystems. Hydrobiologia, 229, 181-198.

Wetzel R.G., 2001. Limnology: Lake and River Ecosystems, Academic Press, London, 1006 p.

Wetzel R.G. and Likens G.E., 1991. Limnological Analyses, Springer-Verlag, New York, 391 p.

Wielgat-Rychert M., Rychert K. and Ficek D., 2010. Factors controlling pelagic production and respiration in a shallow polymictic lake. Pol. J. Ecol., 58, 379-385.

Wielgat-Rychert M., Jarosiewicz A., Ficek D., Pawlik M., Rychert K., 2015. Nutrient fluxes and their impact on the phytoplankton in a shallow coastal lake. Pol. J. Environ. Stud., 24, 751-759.

Williams P.J.leB. and Robertson J.E., 1991. Overall planktonic oxygen and carbon dioxide metabolisms: the problem of reconciling observations and calculations of photosynthetic quotients. J. Plankton Res. 13 (Suppl.), 153-169.

Wolnomiejski N. and Witek Z., 2013. The Szczecin Lagoon Ecosystem: The Biotic Community of the Great Lagoon and its Food Web Model, Versita, London, 293 p. 